Vol. 02 No. 2 Januari - Juni 2015, h. 29-42

\title{
Profil Kemampuan Matematika Dasar Mahasiswa Program Studi Pendidikan Matematika Tahun Akademik 2013/2014
}

\author{
Muhamad Sabirin, Analisa Fitria \\ dan Seri Ningsih
}

\begin{abstract}
Abstrak
Kemampuan Matematika Dasar adalah kemampuan yang sangat penting dan harus dimiliki setiap mahasiswa sebagai bekal untuk menempuh perkuliahan di program studi Pendidikan Matematika. Tujuan penelitian ini adalah untuk mengetahui bagaimana profil kemampuan matematika dasar mahasiswa baru jurusan Pendidikan Matematika tahun akademik 2013/2014. Subjek penelitian berjumlah 133 mahasiswa, 92 berasal dari jurusan IPA dan 41 dari non-IPA. Hasil penelitian menunjukkan bahwa kemampuan matematika dasar mahasiswa baru berada pada kategori rendah; kemampuan matematika dasar mahasiswa baru yang berasal dari jurusan IPA berada pada kategori rendah dan kemampuan matematika dasar mahasiswa baru yang berasal dari jurusan non-IPA berada pada kategori sangat rendah.
\end{abstract}

Kata Kunci: Kemampuan Matematika Dasar, jurusan IPA dan non-IPA.

\section{Pendahuluan}

Jurusan Pendidikan Matematika (PMTK) adalah salah satu jurusan yang ada di bawah Fakultas Tarbiyah dan Keguruan IAIN Antasari Banjarmasin. Jurusan ini setiap tahunnya menerima mahasiswa baru sebagai calon guru matematika yang kelak diharapkan menjadi guru matematika yang professional, berdedikasi tinggi dan berakhlak mulia.

Mahasiswa baru yang diterima pada tahun akademik 2013/2014 terbagi dalam 3 jalur seleksi, yaitu jalur prestasi akademik, jalur ujian tertulis dan jalur mandiri. Jalur prestasi akademik adalah seleksi nasional berdasarkan penjaringan prestasi akademik tanpa ujian tertulis yang pendaftarannya dilakukan secara online. Tidak ada biaya pendaftaran dan pelaksanaan ditanggung sepenuhnya oleh pemerintah. Jalur ujian tertulis adalah seleksi melalui ujian tertulis yang dilakukan serentak secara nasional di seluruh perguruan tinggi di Indonesia. Sedangkan jalur mandiri adalah 
Muhamad Sabirin, Analisa Fitria dan Seri Ningsih

seleksi melalui ujian tertulis yang dilaksanakan secara mandiri oleh perguruan tinggi yang bersangkutan.

Salah satu dampak dari adanya 3 jalur seleksi yang dilakukan secara online tersebut adalah tidak terdeteksinya asal jurusan calon mahasiswa sewaktu di SMA/MA. Calon mahasiswa yang berasal dari jurusan IPS, IPA, Keagamaan dan jurusan lainnya bebas mendaftar ke Jurusan/Program Studi dari Perguruan Tinggi yang diminatinya. Pada umumnya calon mahasiswa cenderung kurang memperhatikan kesesuaian antara jurusan/prodi yang dipilih dengan jurusan asal dan kemampuan dasar yang dimilikinya.

Calon mahasiswa untuk jurusan Pendidikan Matematika idealnya berasal dari jurusan IPA dan memiliki kemampuan matematika dasar yang baik sehingga proses pembelajaran selama mereka menempuh kuliah dapat berjalan dengan lancar. Realita yang dihadapi selama ini mahasiswa yang diterima berasal dari latar belakang yang beragam khususnya terkait dengan asal jurusan mereka ketika di SMA/MA. Hal ini sangat mempengaruhi proses pembelajaran selama kuliah karena kemampuan matematika dasar yang mereka kuasai tidak sama dan sangat beragam.

Memang tidak bisa dipungkiri bahwa pencapaian prestasi belajar yang baik terhadap setiap mata kuliah tidak mudah untuk dicapai mahasiswa. Hal ini dikarenakan banyaknya faktor yang mempengaruhinya dan salah satu faktor yang sangat dominan adalah penguasaan mahasiswa terhadap kemampuan matematika dasar yang mereka pelajari di sekolah. Kemampuan matematika dasar (KMD) yang dimaksud dalam penelitian ini adalah kemampuan dalam menyelesaikan soal-soal terkait konsep dasar matematika yang terdiri dari Aljabar, Geometri, Trigonometri, Logika, Kalkulus, dan Statistika \& Peluang. Kemampuan ini sangat penting untuk dikuasai sebagai modal untuk mereka dapat mengikuti setiap mata kuliah dengan baik dan lancar.

Berdasarkan uraian di atas maka perlu dilakukan penelitian untuk mengetahui Profil Kemampuan Matematika Dasar Mahasiswa Baru Jurusan Pendidikan Matematika (PMTK) Tahun Akademik 2013/2014. 
Profil Kemampuan Matematika Dasar Mahasiswa Program Studi Pendidikan Matematika Tahun Akademik 2013/2014

Penguasaan Kemampuan Matematika Dasar dan Prestasi Belajar Mahasiswa diuraikan sebagai berikut. Perkataan prestasi belajar terdiri dari dua kata, yaitu prestasi dan belajar. Kedua kata tersebut mempunyai arti berbeda. Dalam Kamus Besar Bahasa Indonesia (1999 : 787), prestasi diartikan sebagai hasil yang telah dicapai, dilakukan, dikerjakan dan sebagainya. Sedangkan belajar diartikan sebagai proses perubahan tingkah laku (Salam, 2004 : 3). Di lingkungan perguruan tinggi, perubahan tingkah laku yang dialami mahasiswa meliputi empat aspek, yaitu aspek pengetahuan (koginif), aspek perasaan (afektif), aspek keterampilan (psikomotorik), dan aspek kerjasama (kooperatif) (Depdiknas, 2004 : 5).

Perubahan tingkah laku dalam aspek pengetahuan ialah, dari tidak tahu menjadi tahu; dalam aspek afektif ialah, dari tidak disiplin menjadi disiplin; dalam aspek psikomotorik ialah, dari tidak terampil menjadi terampil; dalam aspek kooperatif ialah, dari pertentangan menjadi kerjasama.Terkait di dalam proses belajar, perubahan-perubahan yang dialami oleh mahasiswa dapat dilakukan dengan menggunakan berbagai metode pembelajaran, antara lain tatap muka, pemberian tugas, seminar, lokakarya, kerja praktek, ujian tengah semester, ujian akhir semester, dan sebagainya.Jadi dapat disimpulkan bahwa prestasi belajar adalah suatu hasil yang dicapai mahasiswa setelah mengalami perubahan tingkah laku, baik aspek kognitif, aspek afektif, aspek psikomotorik, dan aspek kooperatif.

Prestasi belajar merupakan hasil yang dicapai setelah belajar. Menurut Hawkins, Florian\&Rouse (2007: 22) bahwa “achievement on the other hand might be defined as being about the progress made by learners over time". Hal ini berarti bahwa prestasi didefinisikan sebagai kemajuan yang dibuat oleh peserta didik. Ditambahkan bahwa "improvements in achievement are associated with increased maturity and are influenced by the environments in which students learn, live and grow'. Perbaikan prestasi berhubungan dengan peningkatan kedewasaan dan dipengaruhi oleh lingkungan di mana seseorang belajar, hidup dan tumbuh. Lingkungan yang 
Muhamad Sabirin, Analisa Fitria dan Seri Ningsih

mendukung seseorang dalam belajar sangat berpengaruh terhadap peningkatan prestasi belajarnya.

Prestasi terkait dengan kondisi dari dalam dan luar diri seseorang. Orang tua tidak bisa dipungkiri berkontribusi besar dalam meningkatkan prestasi. Menurut Stevenson, Shin-Ying Lee \& Stigler (1998: 697) bahwa orang tua memberikan kekuatan yang berpengaruh sangat besar terhadap kepercayaan diri anak untuk berhasil. Contohnya, orang tua yang menekankan bahwa kecakapan adalah hal penting untuk sukses.

Prestasi belajar berhubungan dengan tingkat keberhasilan suatu tujuan. Hal ini terjadi akibat dari suatu proses belajar yang telah dilakukan seseorang secara maksimal. Menurut Skemp (1971: 16) bahwa “intelegence is the comulative total of the schemata or mental plans built up through the individuals's interaction with his environment, isofor as his contitusional equipment allow”. Maksudnya kecerdasan adalah keseluruhan dari rencana struktur konseptual atau mental melalui interaksi individu dengan lingkungan mereka secara luas. Selain itu, Borich (2007: 61) mengemukakan bahwa: "an aspect of personality that will influence your learners achievement is their learning style". Ini berarti bahwa aspek kepribadian yang berpengaruh pada prestasi siswa adalah gaya belajar. Gaya belajar mewakili kondisi dalam kelas yang membuat seseorang menyukai belajar.

Pada dasarnya prestasi belajar diperoleh melalui keseluruhan proses pembelajaran. Menurut Jhonson \& Jhonson (2002: 8) bahwa:definisi prestasi berkembang menurut tiga hubungan yaitu: 1) prestasi yang berhubungan dengan tingkah laku; 2) prestasi yang berhubungan dengan hasil dan 3) prestasi yang berhubungan dengan sikap dan waktu. Prestasi yang berhubungan dengan tingkah laku diantaranya kemampuan untuk berkomunikasi, bekerja sama, melakukan berbagai aktivitas motorik dan menyelesaikan permasalahan yang komplek. Prestasi yang berhubungan dengan hasil diantaranya menuliskan tema atau laporan proyek, hasil seni dan memproduksi karya seni. Prestasi yang berhubungan dengan sikap dan waktu diantaranya kebanggaan dalam bekerja, keinginan untuk 
Profil Kemampuan Matematika Dasar Mahasiswa Program Studi Pendidikan Matematika Tahun Akademik 2013/2014

meningkatkan kompetensi secara terus menerus, berkomitmen untuk kualitas, dan penghargaan diri.

Prestasi juga dapat diketahui dari pengaruh model pembelajaran yang diterapkan oleh guru. Sesuai dengan pendapat Joyce, Weil \& Calhoun (2004: 7) bahwa: we measure the effects of various models of teaching not only by how well they achieve the specific objectivities to ward which they are directed (for example, self-esteem, social skill, information, ideas, creativity), but also by how well they increase the ability to learn, which is their fundamental purpose.

Ini berarti bahwa kita mengukur pengaruh dari berbagai modelmodel pengajaran tidak hanya oleh beberapa kriteria yang baik dapat mencapai sasaran khusus terhadap yang mereka arahkan (harga diri, ketrampilan sosial, informasi, gagasan-gagasan kreatif) tetapi melalui bagaimana baiknya model-model pembelajaran dapat meningkatkan kemampuan belajar. Kemampuan yang dimaksud diantaranya menerapkan konsep-konsep, memecahkan masalah, dan sebagainya.

Hasil belajar dipengaruhi oleh beberapa hal. Menurut Bettencourt (Paul Suparno, 1997: 61) hasil belajar dipengaruhi oleh pengalaman peserta didik dengan dunia fisik dan lingkungannya. Hasil belajar seseorang tergantung pada apa yang telah diketahui si peserta didik, konsep-konsep, tujuan, motivasi yang mempengaruhi interaksi dengan bahan yang dipelajari.

Alat untuk mengukur hasil belajar disebut tes hasil belajar. Tes hasil belajar terdiri dari sederetan pertanyaan atau soal sebagai jabaran dari materi belajar yang telah dipelajari. Masing-masing soal mencerminkan kompetensi dasar yang dituntut. Ebel\& Fresbie (1986: 11) menyatakan: "test provide the best information teachers and students ordinarily can get about the success of their efforts to teach and learn".

Terkait dengan prestasi belajar matematika, menurut Romberg (2008: 16-17) : "the results on measures of achievement that confirm 
Muhamad Sabirin, Analisa Fitria dan Seri Ningsih

improved student mathematical performance are very important, we contend that relying solely on outcome measures to judge the value of a standard-based program is insufficient". Ini berarti bahwa hasil pengukuran prestasi yang mengkonfirmasi perkembangan pembelajaran matematika siswa sangat penting, kita berpendapat bahwa mempercayakan hasil pengukuran semata-mata untuk menentukan dasar dari standar program itu tidak cukup. Prestasi belajar harus diukur dari semua tujuan yang dikembangkan, bukan aspek dasarnya saja. Melihat dari satu sisi saja tidak dapat menunjukkan ketercapaian tujuan pembelajaran. Keberhasilan pencapaian tujuan dapat dilihat dengan prestasi belajar.

Prestasi belajar sebagai penguasaan pengetahuan atau ketrampilan yang dikembangkan melalui mata pelajaran, lazimnya ditujukan dengan nilai tes atau angka yang diberikan oleh guru. Menurut Rao (2003: 58) prestasi belajar matematika adalah performa siswa dalam matematika pada suatu ujian. Prestasi belajar matematika tidak lain merupakan hasil akhir dari proses belajar matematika sebagai perwujudan dari segala upaya yang telah dilakukan selama berlangsung proses tersebut yang diukur melalui tes hasil belajar.

Jadi yang dimaksud prestasi belajar matematika adalah performa seseorang dalam matematika pada suatu ujian. Prestasi belajar matematika juga merupakan hasil akhir dari proses belajar matematika sebagai perwujudan dari segala upaya yang telah dilakukan selama berlangsung proses tersebut.

Umumnya faktor-faktor yang mempengaruhi prestasi belajar mahasiswa sangat bervariatif. Menurut Slameto (2003: 54), faktor-faktor tersebut terbagi menjadi dua bagian, yaitu faktor internal dan faktor eksternal.Faktor internal adalah faktor yang berasal dari dalam diri mahasiswa. Salah satunya adalah Penguasaan kemampuan matematika dasar.

Setiap mata kuliah yang tersaji di dalam kurikulum Jurusan Pendidikan Matematika (PMTK) Fakultas Tarbiyah IAIN Antasari 
Profil Kemampuan Matematika Dasar Mahasiswa Program Studi Pendidikan Matematika Tahun Akademik 2013/2014

Banjarmasin umumnya tersusun secara hirarkis dari yang mudah ke yang sulit, dari yang sederhana ke yang kompleks. Selain itu, setiap topik dan subtopik yang termuat dalam masing-masing mata kuliah juga saling keterkaitan antara satu dengan mata kuliah yang lain.

Secara implisit penguasaan dalam setiap mata kuliah matematika menuntut penguasaan akan kemampuan matematika dasar yang merupakan dasar atau modal bagi mereka dalam mempelajari materimateri dalam mata kuliah tersebut.Oleh karenanya, penguasaan mata kuliah dasar atau prasyarat yang melandasi mata kuliah berikutnya haruslah dikuasai terlebih dahulu. Hal ini agar mahasiswa tidak mengalami masalah pada mata kuliah berikutnya.

\section{Metode Penelitian}

Penelitian ini termasuk jenis penelitian lapangan (field research) dan metode yang digunakan dalam penelitian ini adalah metode deskriptif. Nazir (2005: 63) mengatakan bahwa metode deskriptif adalah "suatu metode dalam meneliti sekelompok manusia, suatu objek, suatu set kondisi, suatu sistem pemikiran dengan tujuan untuk membuat deskripsi, gambaran atau lukisan secara sistematis, faktual dan akurat mengenai fakta-fakta serta hubungan antar fenomena yang diselidiki”.

Penelitian dilaksanakan di Fakultas Tarbiyah dan Keguruan Jurusan Pendidikan Matematika (PMTK) IAIN Antasari Banjarmasin. Subjek penelitian adalah mahasiswa baru jurusan PMTK Tahun Akademik 2013/2014 yang berjumlah 133 orang, yang terdiri dari 92 orang dari jurusan IPA dan 41 orang dari jurusan non-IPA.Objek penelitian adalah kemampuan matematika dasar mahasiswa baru jurusan PMTK tahun akademik 2103/2014 yakni kemampuan dalam menyelesaikan soal-soal terkait konsep dasar matematika yang terdiri dari Aljabar, Geometri, Trigonometri, Logika, Kalkulus, dan Statistika \& Peluang.

Data dikumpulkan dengan teknik tes untuk mengukur kemampuan matematika dasar mahasiswa baru jurusan pendidikan matematika tahun 
akademik 2013/2014.Instrumen yang digunakan yang terdiri atas 12 butir soal berbentuk essay. Kemampuan matematika dasar terkait enam komponen konsep dasar matematika yang terdiri dari Aljabar, Geometri, Trigonometri, Logika, Kalkulus, dan Statistika \& Peluang. Masing-masing komponen terdiri dari 2 soal.

Kriteria yang digunakan untuk mengenterpretasikan kemampuan matematika dasar mahasiswa diberikan pada tabel berikut:

Tabel 1. Interpretasi penilaian kemampuan matematika dasar

\begin{tabular}{|c|l|}
\hline Persentase KMD & \multicolumn{1}{|c|}{ Kategori } \\
\hline $80-100$ & Sangat Tinggi \\
\hline $60-<80$ & Tinggi \\
\hline $40-<60$ & Sedang \\
\hline $20-<40$ & Rendah \\
\hline $0-<20$ & Sangat Rendah \\
\hline
\end{tabular}

Data di analisis menggunakan statistik deskriptif untuk melihat profil kemampuan matematika dasar mahasiswa baru jurusan PMTK tahun akademik 2013/2104. Untuk menganalisis data digunakan bantuan software SPSS 11.5 for windows.

\section{Hasil dan Pembahasan}

\section{Profil Kemampuan Matematika Dasar}

Secara umum profil kemampuan matematika dasar mahasiswa baru jurusan PMTK tahun akademik 2013/2014 dapat dilihat pada tabel berikut: 
Profil Kemampuan Matematika Dasar Mahasiswa Program Studi Pendidikan Matematika Tahun Akademik 2013/2014

\begin{tabular}{|c|c|c|c|c|}
\hline Konsep Dasar & No. Soal & Benar & $\%$ & Rata-Rata (\%) \\
\hline \multirow[t]{3}{*}{ Aljabar } & $1 a$ & 104 & 78,20 & \multirow[t]{3}{*}{60,90} \\
\hline & $1 b$ & 106 & 79,70 & \\
\hline & 2 & 33 & 24,81 & \\
\hline \multirow[t]{2}{*}{ Geometri } & 1 & 14 & 10,53 & \multirow[t]{2}{*}{8,65} \\
\hline & 2 & 9 & 6,77 & \\
\hline \multirow[t]{2}{*}{ Trigonometri } & 1 & 9 & 6,77 & \multirow[t]{2}{*}{12,03} \\
\hline & 2 & 23 & 17,29 & \\
\hline \multirow[t]{2}{*}{ Logika } & 1 & 37 & 27,82 & \multirow[t]{2}{*}{15,04} \\
\hline & 2 & 3 & 2,26 & \\
\hline \multirow[t]{3}{*}{ Kalkulus } & 1a & 35 & 26,32 & \multirow[t]{3}{*}{18,05} \\
\hline & $1 b$ & 23 & 17,29 & \\
\hline & 2 & 14 & 10,53 & \\
\hline \multirow[t]{2}{*}{ Statistika dan Peluang } & 1 & 15 & 11,28 & \multirow[t]{2}{*}{6,02} \\
\hline & 2 & 1 & 0,75 & \\
\hline \multicolumn{4}{|c|}{ Rata-Rata } & 22,88 \\
\hline
\end{tabular}

Berdasarkan tabel di atas dapat dilihat bahwa secara umum rata-rata kemampuan matematika dasar mahasiswa masih rendah yakni pada kisaran rata-rata $22.88 \%$. Jika dilihat berdasarkan setiap bidang konsep dasar yang di ukur, hanya pada bidang Aljabar yang menunjukkan bahwa kemampuan matematika dasar mahasiswa berada pada kategori tinggi yakni sebesar $60.90 \%$. Sedangkan pada kelima bidang yang lain yakni Geometri, Trigonometri, Logika, Kalkulus dan Statistika \& Peluang berada pada kategori sangat rendah, yakni masing-masing berturut-turut sebesar 8,65\%, $12,03 \%, 15,04 \%, 18,05 \%$ dan $6,02 \%$.

Berdasarkan hasil di atas terlihat bahwa bidang Statistika \& Peluang dan Geometri merupakan bidang yang memiliki kemampuan tersulit dari seluruh bidang yang lain pada instrument tes kemampuan matematika dasar yang diukur dalam penelitian ini.

\section{Profil Kemampuan Matematika Dasar Jurusan IPA}


Muhamad Sabirin, Analisa Fitria dan Seri Ningsih

Profil kemampuan matematika dasar mahasiswa baru jurusan PMTK yang berasal dari jurusan IPA sebanyak 92 orang disajikan dalam tabel berikut:

Tabel 3. Profil Kemampuan MatematikaDasar Jurusan IPA

\begin{tabular}{|c|c|c|c|c|}
\hline Konsep Dasar & No. Soal & Benar & $\%$ & Rata-Rata (\%) \\
\hline \multirow[t]{3}{*}{ Aljabar } & $1 \mathrm{a}$ & 72 & 78,26 & \multirow[t]{3}{*}{62,68} \\
\hline & $1 b$ & 74 & 80,43 & \\
\hline & 2 & 27 & 29,35 & \\
\hline \multirow[t]{2}{*}{ Geometri } & 1 & 12 & 13,04 & \multirow[t]{2}{*}{10,33} \\
\hline & 2 & 7 & 7,61 & \\
\hline \multirow[t]{2}{*}{ Trigonometri } & 1 & 8 & 8,70 & \multirow[t]{2}{*}{15,22} \\
\hline & 2 & 20 & 21,74 & \\
\hline \multirow[t]{2}{*}{ Logika } & 1 & 32 & 34,78 & \multirow[t]{2}{*}{19,02} \\
\hline & 2 & 3 & 3,26 & \\
\hline \multirow[t]{3}{*}{ Kalkulus } & $1 a$ & 33 & 35,87 & \multirow[t]{3}{*}{22,83} \\
\hline & $1 b$ & 18 & 19,57 & \\
\hline & 2 & 12 & 13,04 & \\
\hline \multirow[t]{2}{*}{ Statistika dan Peluang } & 1 & 10 & 10,87 & \multirow[t]{2}{*}{5,98} \\
\hline & 2 & 1 & 1,09 & \\
\hline \multicolumn{4}{|c|}{ Rata-Rata } & 25,54 \\
\hline
\end{tabular}

Berdasarkan tabel di atas dapat dilihat bahwa rata-rata kemampuan matematika dasar mahasiswa yang berasal dari jurusan IPA berada pada kategori rendah yakni sebesar 25.54\%. Berdasarkan setiap bidang konsep dasar yang di ukur, pada bidang Aljabar kemampuan matematika dasar mahasiswa berada pada kategori tinggi yakni sebesar 62.68\%. Kemampuan matematika dasar pada bidang Kalkulus berada pada kategori rendah yakni sebesar 22,83\%. Sedangkan pada bidang Geometri, Trigonometri, Logika, dan Statistika \& Peluang berada pada kategori sangat rendah, yakni masing-masing berturut-turut sebesar 10,33\%, 15,22\%, 19,02\%, dan 5,98\%.Bidang Statistika \& Peluang dan Geometri juga merupakan bidang yang memiliki kemampuan tersulit dari seluruh bidang yang lain bagi mahasiswa yang berasal dari jurusan IPA.

Profil Kemampuan Matematika Dasar Jurusan Non-IPA 
Profil Kemampuan Matematika Dasar Mahasiswa Program Studi Pendidikan Matematika Tahun Akademik 2013/2014

Profil kemampuan matematika dasar mahasiswa baru jurusan PMTK yang berasal dari jurusan Non-IPA sebanyak 41 orang disajikan dalam tabel berikut:

Tabel 4. Profil Kemampuan Matematika Dasar Jurusan Non-IPA

\begin{tabular}{|c|c|c|c|c|}
\hline Konsep Dasar & No. Soal & Benar & $\%$ & Rata-Rata (\%) \\
\hline \multirow[t]{3}{*}{ Aljabar } & $1 \mathrm{a}$ & 32 & 78,05 & \multirow[t]{3}{*}{56,91} \\
\hline & $1 b$ & 32 & 78,05 & \\
\hline & 2 & 6 & 14,63 & \\
\hline \multirow[t]{2}{*}{ Geometri } & 1 & 2 & 4,88 & \multirow[t]{2}{*}{4,88} \\
\hline & 2 & 2 & 4,88 & \\
\hline \multirow[t]{2}{*}{ Trigonometri } & 1 & 1 & 2,44 & \multirow[t]{2}{*}{4,88} \\
\hline & 2 & 3 & 7,32 & \\
\hline \multirow[t]{2}{*}{ Logika } & 1 & 5 & 12,20 & \multirow[t]{2}{*}{6,10} \\
\hline & 2 & 0 & 0,00 & \\
\hline \multirow[t]{3}{*}{ Kalkulus } & 1a & 2 & 4,88 & \multirow[t]{3}{*}{7,32} \\
\hline & $1 \mathrm{~b}$ & 5 & 12,20 & \\
\hline & 2 & 2 & 4,88 & \\
\hline \multirow[t]{2}{*}{ Statistika dan Peluang } & 1 & 5 & 12,20 & \multirow[t]{2}{*}{6,10} \\
\hline & 2 & 0 & 0,00 & \\
\hline \multicolumn{4}{|c|}{ Rata-Rata } & 16,90 \\
\hline
\end{tabular}

Berdasarkan tabel di atas dapat dilihat bahwa rata-rata kemampuan matematika dasar mahasiswa yang berasal dari jurusan Non-IPA berada pada kategori sangat rendah yakni sebesar 16.90\%. Berdasarkan setiap bidang konsep dasar yang di ukur, pada bidang Aljabar kemampuan matematika dasar mahasiswa berada pada kategori sedang yakni sebesar 56.91\%. Sedangkan pada bidang Geometri, Trigonometri, Logika, Kalkulus, dan Statistika \& Peluang berada pada kategori sangat rendah, yakni berada dibawah 7,50\%.Semua bidang selain Aljabar merupakan materi yang sulit bagi mahasiswa yang berasal dari jurusan non-IPA. 
Muhamad Sabirin, Analisa Fitria dan Seri Ningsih

Berdasarkan hasil analisis dari lembar jawaban mahasiswa, ditemukan beberapa faktor yang mempengaruhi rendahnya kemampuan matematika dasar mahasiswa sebagai berikut: (1) Aljabar, kesulitan dalam menentukan akar-akar persamaan kuadrat dengan $a>1$ dan kurang menguasai konsep perkalian bilangan berpangkat. (2) Geometri, kurang menguasai konsep Keliling Bangun Datar, khususnya Lingkaran dan Persegi, dan kurang menguasai konsep Luas Bangun Datar, khususnya Persegi, Persegi panjang dan Segitiga. (3) Trigonometri, kurang menguasai konsep Identitas Trigonometri dan kurang menguasai konsep Sinus dan Cosinus dari suatu sudut. (4) Logika, kurang menguasai konsep Ingkaran atau Negasi dari suatu pernyataan dan kurang menguasai konsep ekivalensi, khususnya bentuk implikasi ( $\rightarrow$ q) dan Kontra Posisi $(\sim q \rightarrow \sim p$ ). (5) Kalkulus, kurang menguasai konsep Turunan, khususnya turunan fungsi aljabar dan trigonometri dan kurang menguasai konsep Integral, khususnya integral tertentu dari fungsi aljabar. (6) Statistika \& Peluang, kurang menguasai konsep Rata-Rata Hitung (Mean) dari suatu data dan kurang menguasai konsep Peluang dari suatu kejadian.

\section{Kesimpulan}

Berdasarkan hasil yang diperoleh dari penelitian ini dapat disimpulkan bahwa: (1) Kemampuan Matematika Dasar mahasiswa baru tahun Akademik 2013/2014 berada pada kategori Rendah. (2) Kemampuan Matematika Dasar mahasiswa baru tahun Akademik 2013/2014 dari Jurusan IPA berada pada kategori Rendah. (3) Kemampuan Matematika Dasar mahasiswa baru tahun Akademik 2013/2014 dari Jurusan Non-IPA berada pada kategori Sangat Rendah.

Berdasarkan hasil yang diperoleh dari penelitian ini dapat disarankan bahwa: (1) Perlu adanya matrikulasi untuk menyamakan kemampuan matematika dasar mahasiswa dengan latar belakang jurusan asal yang berbeda-beda. (2) Perlu adanya revisi kurikulum bagi jurusan PMTK yang lebih berfokus pada materi matematika sekolah sebagai bekal dan untuk 
Profil Kemampuan Matematika Dasar Mahasiswa Program Studi Pendidikan Matematika Tahun Akademik 2013/2014

memperkuat penguasaan Kemampuan Matematika Dasar. (3) Perlunya mempertimbangkan asal jurusan sebagai syarat masuk bagi Penerimaan Mahasiswa Baru Jurusan PMTK karena adanya perbedaan yang cukup jauh antara yang berasal dari jurusan IPA dan non-IPA.

\section{Daftar Pustaka}

Burhanuddin Salam. Cara Belajar Yang Sukses di Perguruan Tinggi. Jakarta. Rineka Cipta. 2004.

Borich, G.D. (2007). Effective teaching methods: research-based practice.Upper Saddle River: Prentice Hill.

Chambers, P. (2008). Teaching mathematics; developing as a reflective secondary teacher. London: SAGE.

Departemen Pendidikan dan Kebudayaan. Kamus Besar Bahasa Indonesia. Jakarta. Balai Pustaka. 1999.

Depdiknas. Praktek Baik Dalam Penjaminan Mutu Pendidikan Tinggi Buku 1 Pembelajaran. Jakarta. Ditjen. 2004.

Ebel, R.I., \& Frisbie, D.A. (1986). Essensial of education measurement (4th $^{\text {th }}$ ed). Englewood Cliffts: Prentice-Hall, Inc.

Hawkins, K.B., Florian, L., \& Rouse, M. (2007). Achievement and inclusion in schools. New York: Routledge.

Johnson, D.W., \& Johnson, R.G. (2002). Meaningful assessment. Boston: Allyn \& Bacon.

Joyce, B., Weil, M., \& Calhoun, E. (2004). Models of teaching (7th ed). Thousand Oaks: Pearson Education.

Nazir, M. Metode Penelitian. Jakarta. Ghalia Indonesia. 2005.

Romberg, T.A. (2008). The impactof reform instruction on student mathematics achievement. New York: Pearson Education, Inc.

Skemp, R.R. (1971). The psychology of learning mathematics. Victoria: Penguin Books Australia Ltd.

Slameto. Belajar dan Faktor-Faktor Yang Mempengaruhinya. Jakarta. Rineka Cipta. 2003. 
Muhamad Sabirin, Analisa Fitria dan Seri Ningsih

Suharsimi Arikunto. Prosedur Penelitian; Suatu Pendekatan Praktik. (Jakarta:Rineka Cipta. 2010). h.130.

Suparno, Paul. (1997). Filsafat konstruktivisme dalam pendidikan. Bandung: Pustaka Filsafat.

Stevenson, H.W., Shin-Ying Lee, \& Stigler, J.W. (1998). Mathematics achievement of Chinese, Japanese and American Children. Science,231,633-699.

http://www.spa.ucla.edu/ps/pdf/s99/PS294assign/achivement.pdf

Winkel, W.S. (1996). Psikologi pengajaran. Jakarta: PT Gramedia Widiasarana Indonesia.

Dr. Muhammad Sabirin, S.Pd., M.Si

Dosen Prodi PMTK, IAIN Antasari Banjarmasin

E-mail: m.sbrn@yahoo.co.id

Analisa Fitria, S.Pd., M.Si

Dosen Prodi PMTK, IAIN Antasari Banjarmasin

E-mail: analisafitria@iainantasari.ac.id

Seri Ningsih, M.Pd

Dosen Prodi PMTK, IAIN Antasari Banjarmasin

E-mail: seri.ningsih02@gmail.com 